\title{
Factors Influencing Teachers' Engagement
}

\author{
Salama Abdul Aziz Al Ruqaishi, ${ }^{1, *}$ \\ ${ }^{1}$ University of Nizwa, Oman \\ *Corresponding author: University of Nizwa, Oman. E-mail: s.alruqaishi@unizwa.edu.om
}

Received: March 1, 2021 Accepted: September 3, 2021 Published: January 14, 2022

doi:10.5296/ije.v14i1.18366 URL: https://doi.org/10.5296/ije.v14i1.18366

\begin{abstract}
This study is about teachers' engagement in a University Foundation Programme in Oman. In particular, the study probes the learning-teaching beliefs that both teachers and students hold inside the classroom in an Omani context. These students are in their first university year and come from a range of settings in Oman, so these learning beliefs could result from learning styles in the school being different to those in a university. The students were not used to be taught English as a second language in schools and they are not used to be taught by native speakers of the language. These changes in students' learning environment could influence teachers' engagement inside the classroom. This study used both quantitative and qualitative methods to answer the research questions. The Engaged Teacher Scale (ETS) and the Questionnaire on Teacher Interaction (QTI) were both used in this study. The Engaged Teacher Scale was in teachers' questionnaire, students' questionnaire and in the form of a closed diary every two weeks. The Questionnaire on Teacher Interaction (QTI) had two versions, one for teachers and one for students. Semi-structured interviews were conducted for both teachers and students to give reasons for their responses in the questionnaires and diaries. Analysis of variance showed a main effect of Students' Level on their Social Engagement with their teachers. Teachers' data also shows that Pre-Foundation (A) teachers were more socially engaged with their students which agree with the students' data, but Social Engagement was not significant with Teachers' data. Results from Teachers' Diaries also indicated that participants did rate the three Emotional Engagement differently and that these differences were statically significant. This showed the importance of Teachers' Emotional Engagement when the decreasing significance of Emotional Engagement can decrease all components of Teachers' Engagement.
\end{abstract}

Keywords: Teachers' Engagement, Learning-Teaching Beliefs, Engaged Teacher Scale (ETS), Questionnaire on Teacher Interaction (QTI) 


\section{Introduction}

\subsection{Scope and Importance of the Study}

Work engagement was analysed in the literature review with relation to administration job demand. It was also considered with regard to management. This study identifies work engagement in the area of education, since it is about teacher engagement. In addition, learningteaching mismatch has been acknowledged in the Omani context, but not related to teacher engagement. Cultural mismatch was also pointed out, but not discussed in the Omani context or in terms of teacher engagement. This study explores teachers' emotional and social engagement and teacher-student mismatch.

There are differences between the teaching of English in schools and in universities in Oman. For example, in government schools, English is taught as a foreign language, while students learn other subjects in Arabic. In comparison, at university, English is used as a second language to teach all courses. Students are expected to communicate in and study all courses using English. Many students find this a big challenge to learn English during their first year at university.

Since "the emphasis on social relationships with students characterises the heart of the work of teaching" (Klassen, Yerdelen, \& Durksen, 2013), this study considers whether there is a relationship between the mismatch students experience and teachers' emotional and social engagement inside the classroom. This is because effective teaching is more related to emotional and social engagement inside the classroom. It also discussed how the teachers' engagement affected by this mismatch may change over time, and how teachers' engagement can affect teacher-student relationships.

The study sheds light on students' different experiences of learning English at university level compared with school. Since, moreover, "teachers usually teach in the way they were taught or learned best or emulate teachers they admired" (Matthew, 2001, p. 5), the study guides teachers using the learning styles preferred by students. Teachers and students can also understand each other's culture.

If this mismatch between teachers and students could be overcome, then there would be more positive relationships, and they would become more engaged inside the classroom.

\subsection{Higher Education in Oman}

When students in Oman finish grade 12, they study at a higher education college or university. The Oman Accreditation Council (OAC) follows international rules to guarantee the quality of higher education by supervising institutions, including colleges and universities. In 2007, the OAC established a new rule that any students who finished grade 12 and enrolled at a higher education institution must attend a General Foundation Programme (GFP). This programme includes many courses, such as English Language, Maths and Computer Skills and General Study Skills. However, students are not required to take the English Language course if they score 5.0 in the IELTS exam, with at least 4.5 in all the four skills (writing, speaking, listening and reading), or 500 in TOEFL. 


\subsubsection{Education Reform}

However, according to Ali S Al-Issa \& Al-Bulushi ( 2012, p. 142), "the vast majority of the students who leave Grade 12 and join different public and private higher education academic institutions lack the ability to use language effectively and appropriately in all four skills throughout the range of social, personal, school and work situations required for daily living in a given society". For this reason, a new educational system was introduced in Oman. This new system, called the Basic Education System (BES), was launched in 1999. Omani students start learning English as a foreign language in school from Grade 1. In addition, the new BES uses new methodology in teaching English, such as Communicative Language Teaching (CLT), and all school subjects.

\subsubsection{Education Reform and Reality}

Despite the BES, which was introduced in 1999, Al-Issa \& Al-Bulushi(2012, p. 146) note that in 2008, the World Bank development report on MENA countries (Middle East and North Africa) confirmed that "there is a gap between what the MENA educational systems currently produce and the needs to achieve their development objectives". There exists a gap because teaching in MENA countries is mostly about "delivering and memorising facts, repetition of definitions, passive reception of knowledge, acquisition of declarative knowledge at the expense of procedural knowledge, textbook dependency, didactic, adoption of teachercenteredness, while giving less attention to individual differences in the classroom, interactive learning, student-centeredness, and the introduction and development of higher-order cognitive skills" (Al-Issa \& Al-Bulushi, 2012, p. 147). Akkari( 2004, p. 151) explains that "Today's students must be taught the technical skills that are needed to function effectively in tomorrow's world." According to Akkari (2004), "technical skills" means "problem solving, critical thinking, innovation, creativity and cooperation". Furthermore, for Al-Zufairy(2003), one of the reasons for the "unemployment crises" in the Gulf countries is having a system of education which does not qualify graduates for the job market.

\subsubsection{Teachers' Role in the Educational Reform}

Teachers are considered the most important factor in any educational system. They are expected to meet students' needs by applying new methods of teaching. Unfortunately, the World Bank development reports on MENA countries reveal that teachers are still considered as "factory workers along a production chain, delivering a range of skills and knowledge to a homogenous group of students" (Mondiale, 2008, p. 291). In addition, some English teachers in Omani schools are still using Grammar-Translation and Audio-Lingual methods (Al-Issa, 2002). However, others are applying new methods of teaching in schools and following the training programmes of the new Basic Education System (BES). According to Al-Issa (2002) and Al-Toubi( 1998), school assessment is based mostly on memorisation and learning English for exam purposes. This makes it difficult for students to use higher-thinking skills, such as analysis and discussion. Al-Issa (2006b) proposes more developed programmes to prepare teachers and supervisors to help the students to reach a high level of English proficiency. 


\section{Place of Study}

The Foundation Institute at this university prepares the students for their academic study by offering basic, obligatory courses, which should be taken in their first year. These are academic courses in English, maths, computer skills and life-long learning skills. One of the main aims of the Foundation Institute is to prepare the students for their specialisation courses by having the necessary English, maths and computer skills. Life-long learning skills courses also help the students to adjust to university life and to develop independent learning and critical thinking.

\section{Research Questions}

The main aims of this study were to identify the learning-teaching beliefs that both foundation students and teachers at an Omani University experience and how these beliefs can influence their teachers' emotional and social engagement within the classroom and teacher-student relationships. These learning-teaching beliefs could be considered as one of the job demands that need job resources. This study also identified how teachers' emotional and social engagement can influence the relationships between teachers and their students. These aims could be obtained by answering the following questions:

1-Do different domains of teachers' engagement (e.g. emotional and social engagement) change over time? (Diary data)

\section{2-Is there a difference between beginner and advanced students in their social} engagement and relationship with their teachers? (Questionnaire data)

Diaries were given to 56 teachers. These diaries were given to the teachers every two weeks. These diaries consist of Engagement Teacher Scale (EE "Emotional Engagement" and SES "Social Engagement with Students") which are eight closed questions with one open question at the end about the challenges teachers face inside the classroom.

Table 1. Composite of Emotional Engagement Diaries

\begin{tabular}{lccc}
\hline \multicolumn{3}{c}{ Descriptive Statistics } & \\
\hline & Mean & Std. Deviation & $\mathrm{N}$ \\
\hline $\begin{array}{l}\text { Composite of Four Emotional Engagement First } \\
\text { Diary }\end{array}$ & 4.7813 & 1.15706 & 56 \\
$\begin{array}{l}\text { Composite of Four Emotional Engagement } \\
\text { Second Diary }\end{array}$ & 4.6205 & 1.17260 & 56 \\
$\begin{array}{l}\text { Composite of Four Emotional Engagement } \\
\text { Third Diary }\end{array}$ & 4.3661 & 1.42379 & 56 \\
\hline
\end{tabular}




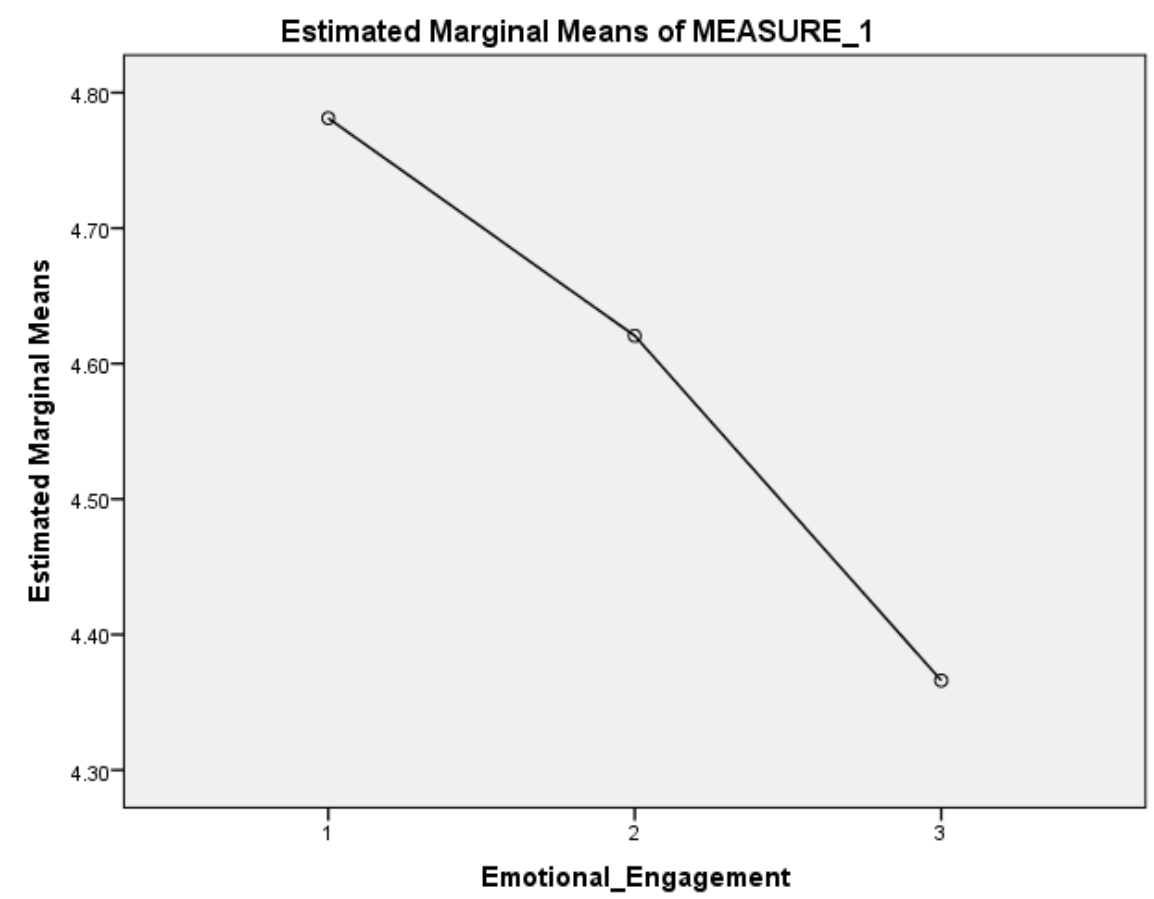

Figure 1. Changing in Teachers' Emotional Engagement over Time

Results indicated that participants did rate the three emotional engagement differently and that these differences were statistically significant, $F(1.96,107.70)=7.14, p<0.01$, eta $^{2}=.12$

Table 2. Composite of Teacher's Social Engagement Diaries

\begin{tabular}{lccc}
\hline \multicolumn{3}{c}{ Descriptive Statistics } & \\
\hline & Mean & Std. Deviation & $\mathrm{N}$ \\
\hline $\begin{array}{l}\text { Composite of Four Social Engagement } \\
\text { with Students First Diary }\end{array}$ & 5.2768 & .66003 & 56 \\
$\begin{array}{l}\text { Composite of Four Social Engagement } \\
\text { with Students Second Diary }\end{array}$ & 5.1979 & .77956 & 56 \\
$\begin{array}{l}\text { Composite of Four Social Engagement } \\
\text { with Students Third Diary }\end{array}$ & 5.1652 & .89732 & 56 \\
\hline
\end{tabular}




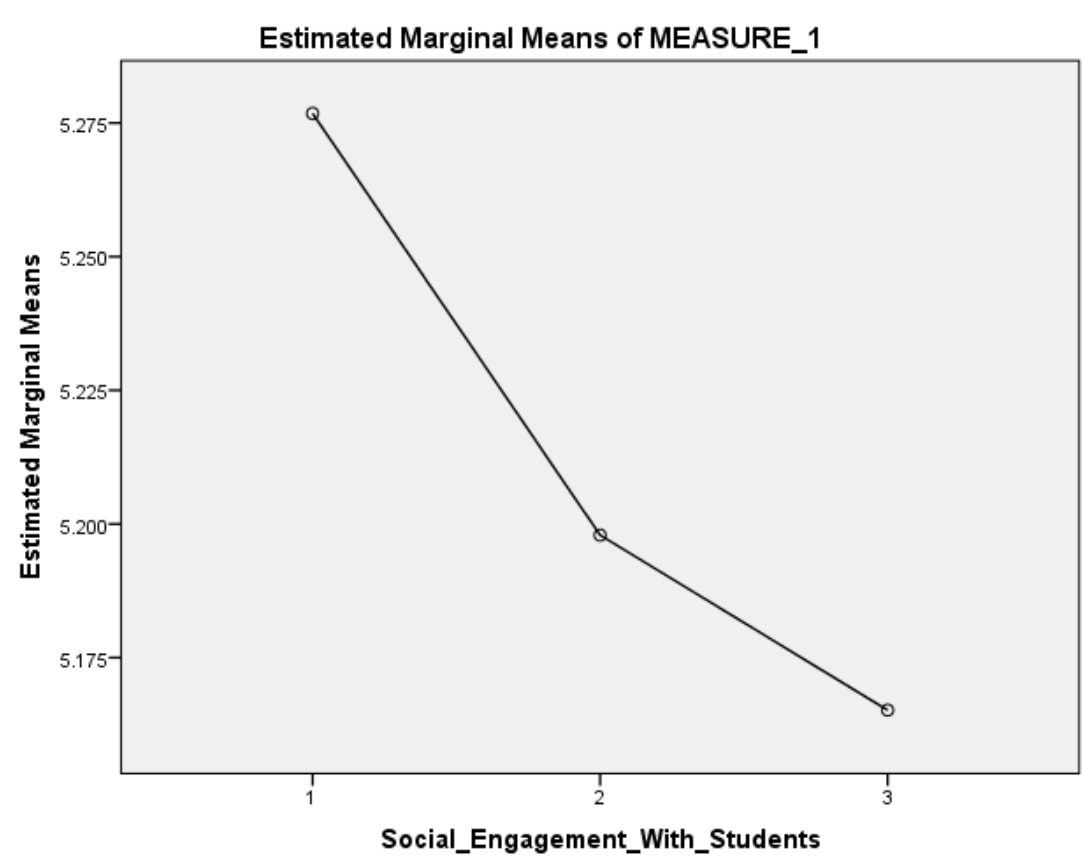

Figure 2. Changing in Teachers' Social Engagement over Time

Results indicated that participants did rate the three social engagement with students differently and that these differences were not statistically significant: $F(1.73,95.36)=1.12, p>0.05$, $\operatorname{eta}^{2}=.02$.

Table 3. Composite of Total Teacher Engagement Diaries

\begin{tabular}{lccc}
\hline \multicolumn{4}{c}{ Descriptive Statistics } \\
\hline $\begin{array}{l}\text { Composite of Eight Components of } \\
\text { Teacher Engagement Scale First Diary }\end{array}$ & 5.0290 & Std. Deviation & $\mathrm{N}$ \\
$\begin{array}{l}\text { Composite of Eight Components of } \\
\text { Teacher Engagement Scale Second Diary }\end{array}$ & 4.9082 & .80622 & 56 \\
$\begin{array}{l}\text { Composite of Eight Components of } \\
\text { Teacher Engagement Scale Third Diary }\end{array}$ & 4.7656 & .89368 & 56 \\
\hline
\end{tabular}




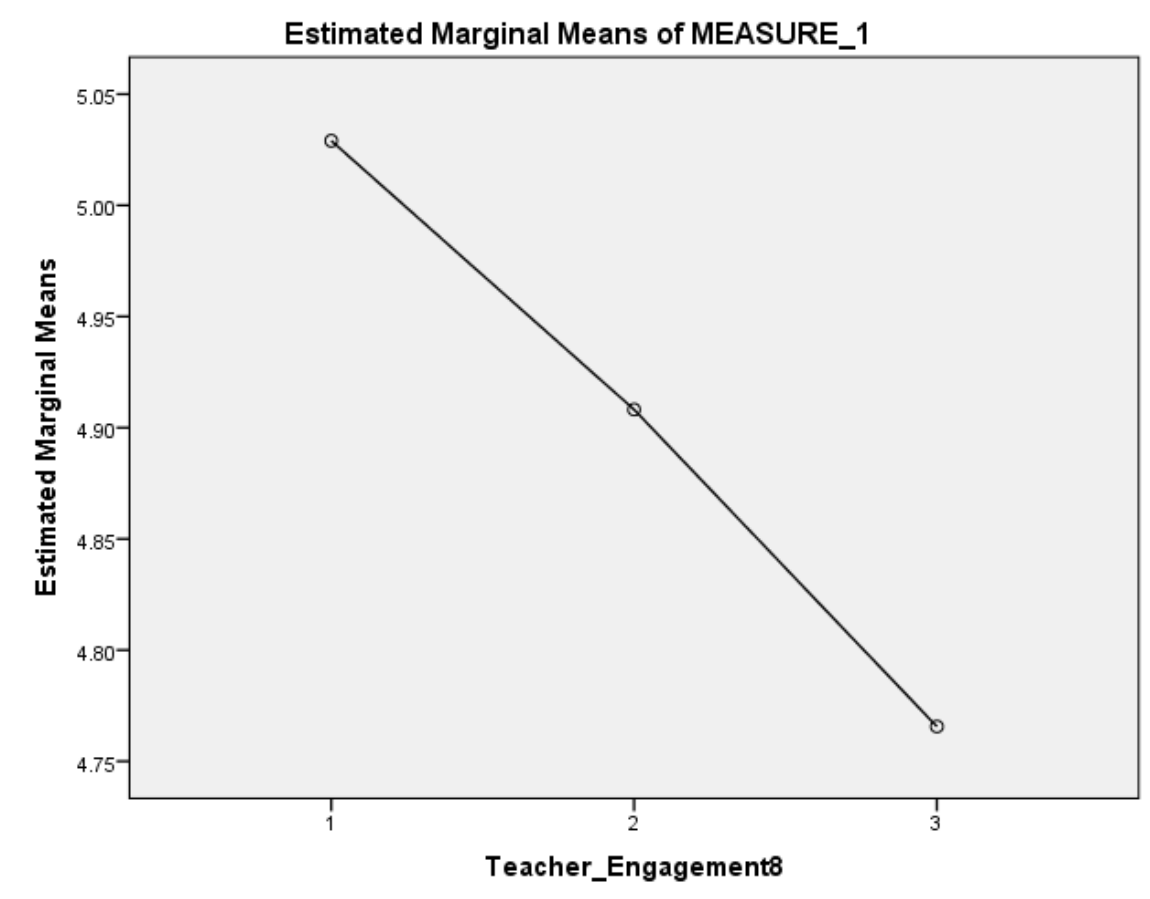

Figure 3. Changing in Total Teacher Engagement over Time

Results indicated that participants did rate the three teacher engagement scale (all eight components) differently and that these differences were statistically significant: $F(1.77,97.30)$ $=5.51, \mathrm{p}<0.01$, eta $^{2}=0.09$. Teacher engagement decreased during the semester, which could be because the semester is too long, as the teachers mentioned in their diaries. Another reason could be that the second and the third diaries were given after the mid-term exams, where some teachers pointed out that students' low results can affect their engagement.

2- Is there a difference between beginner and advanced students in their social engagement and relationship with their teachers? (Questionnaire data)

One-way ANOVA was used to see if students' English level is affecting their social engagement and relationship with their teachers. Students' levels from the lowest English level to the highest are Pre-Foundation A, Pre-Foundation B, Elementary, Elementary Consolidation, Pre-Intermediate, Pre-Intermediate Consolidation. 


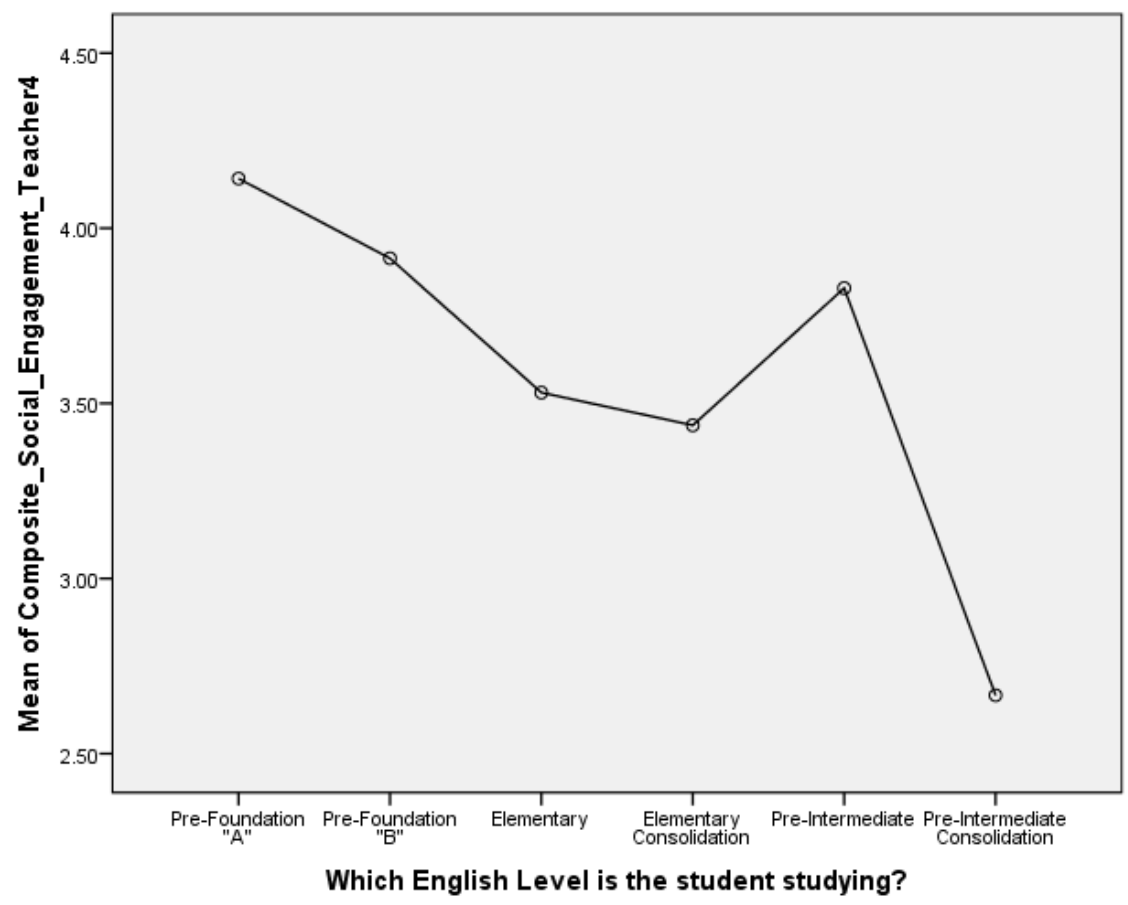

Figure 4. Difference between Students in Social Engagement

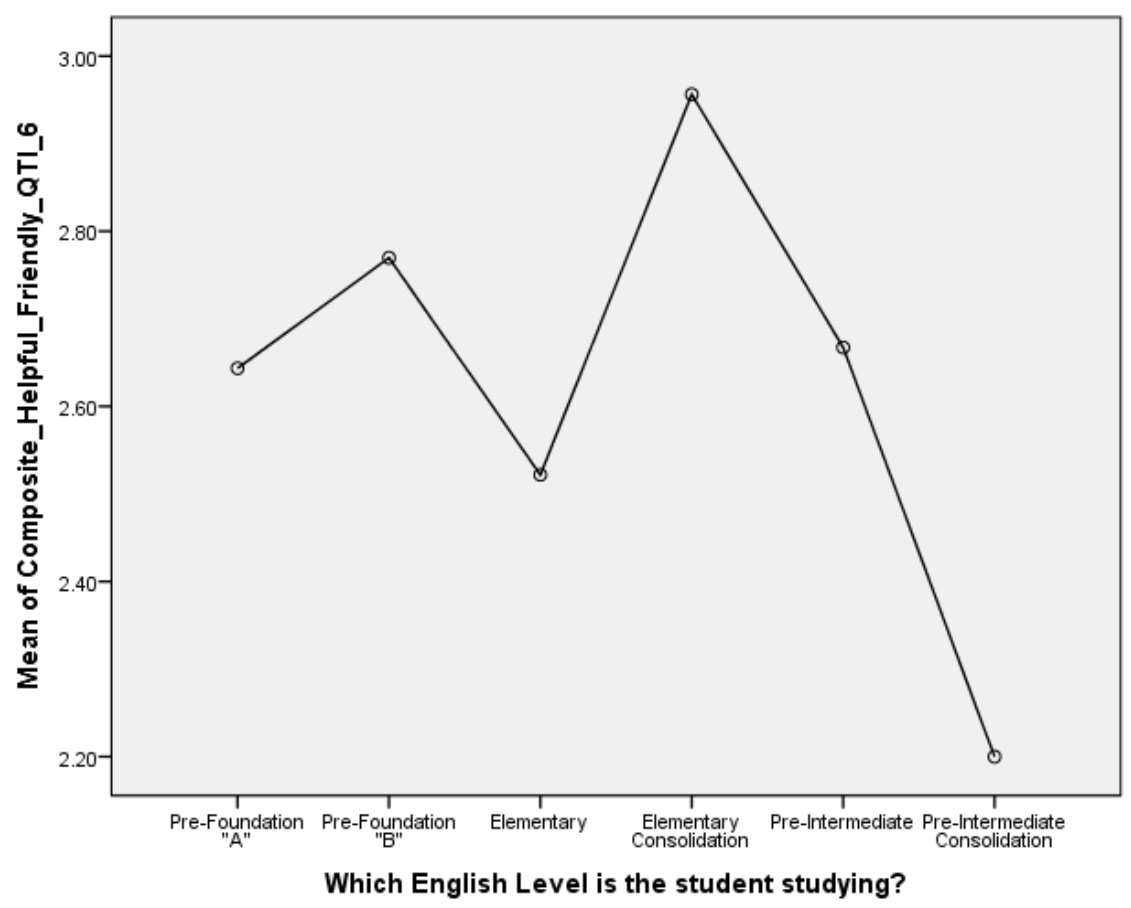

Figure 5. Difference between Students in Helpful/Friendly QTI 


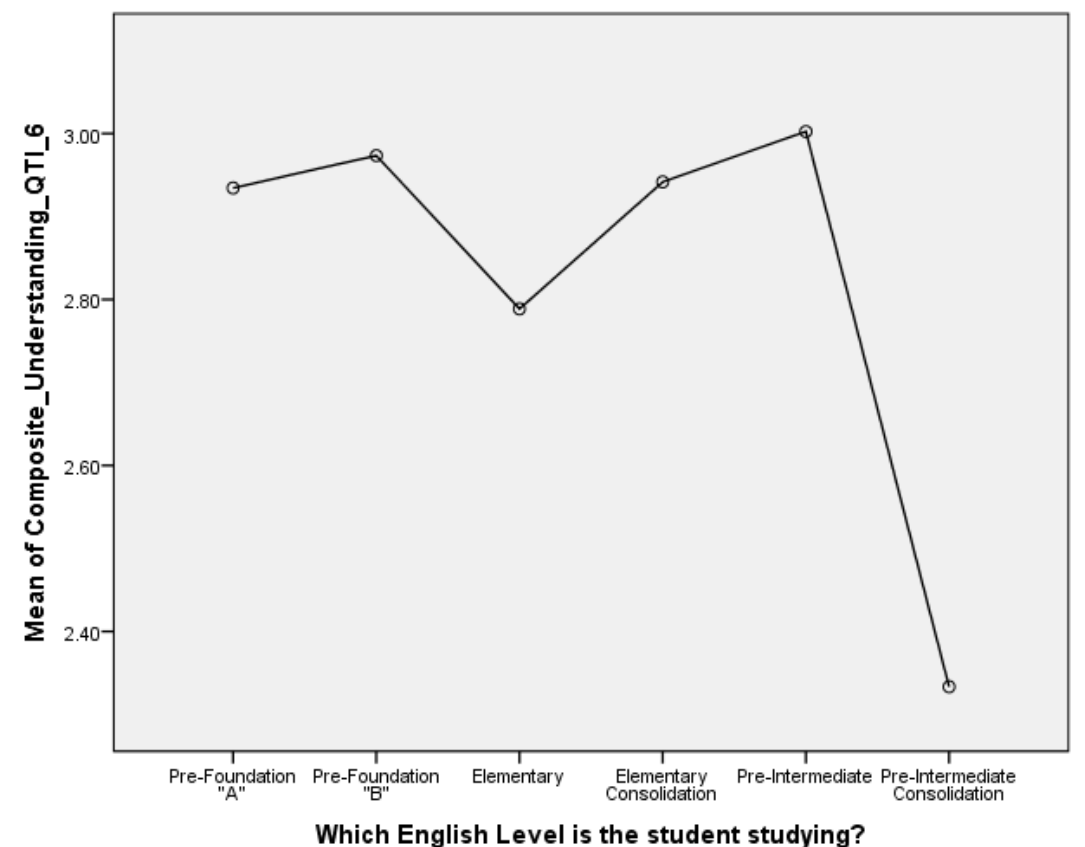

Figure 6. Difference between Students in Understanding QTI

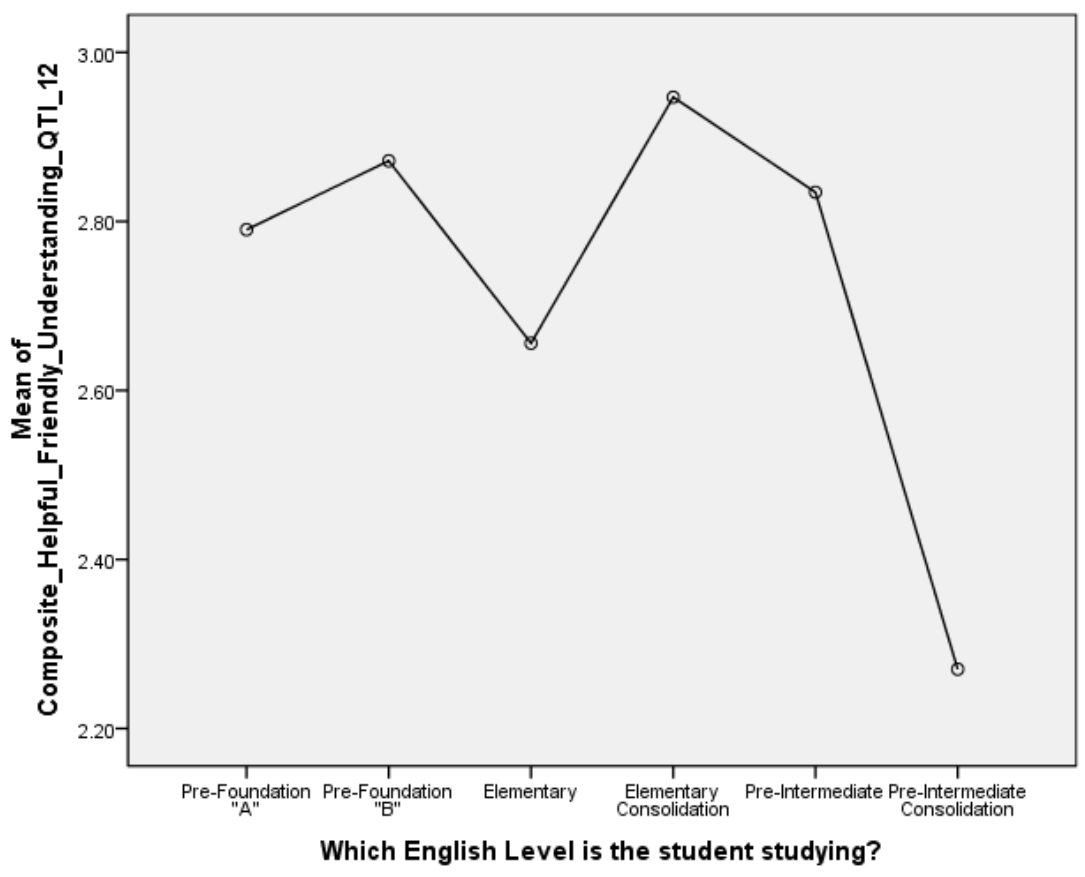

Figure 7. Difference between Students in Total QTI

Analysis of variance showed a main effect of Students' level on their social engagement with their teachers. $\mathrm{F}(5,432)=2.81, \mathrm{p}=.017$.

Post-hoc analyses using Tukey's HSD indicated that there was a significant difference between 


\section{Macrothink}

Pre-Foundation A and Pre-Intermediate Consolidation in their social engagement with their teachers $(\mathrm{p}=.043)$, but students' levels did not differ significantly in any other domains.

It was also noticed that there was a decline from Pre-Intermediate Level to Pre-Intermediate Consolidation Level in all composite scales of social engagement, helpful/friendly and understanding. Another one-way ANOVA was conducted to compare Pre-Intermediate Level to Pre-Intermediate Consolidation Level.

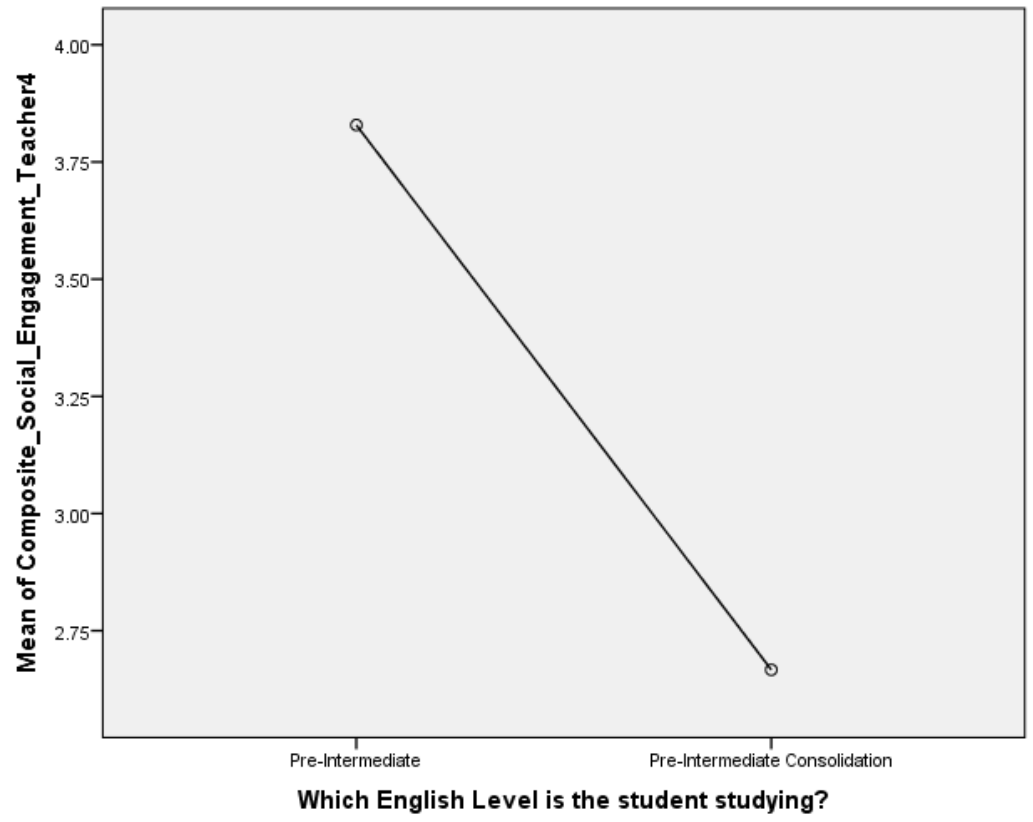

Figure 8. Difference between Pre-Intermediate Students in Social Engagement

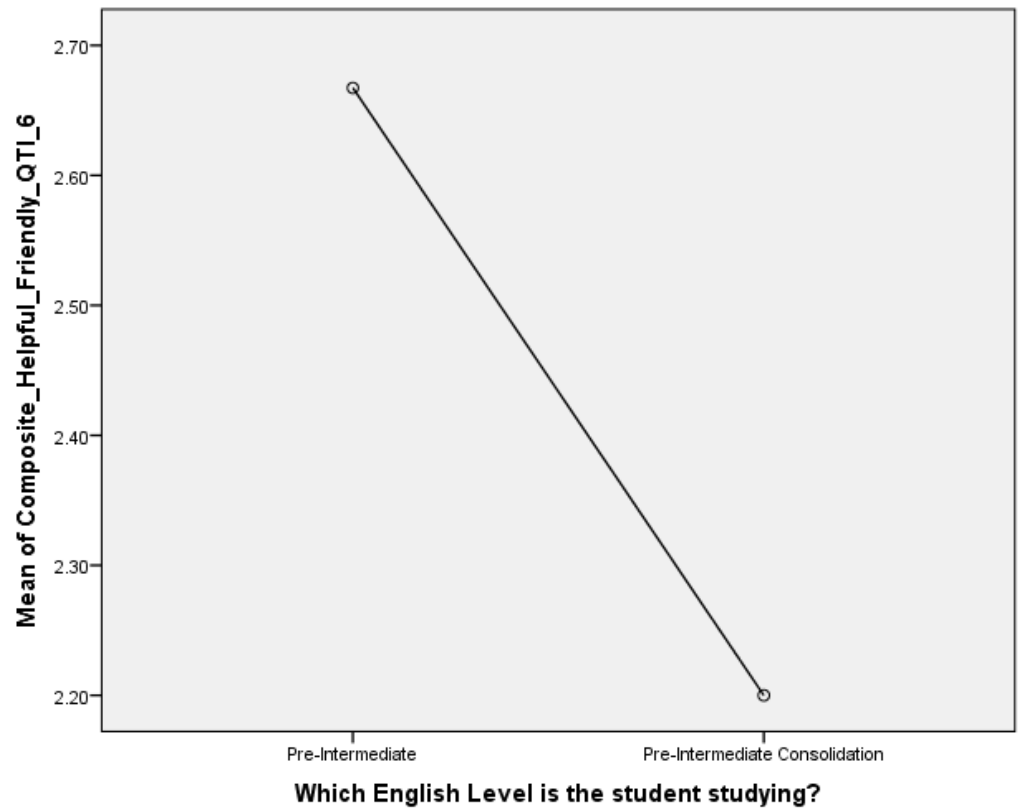

Figure 9. Difference between Pre-Intermediate Students in Helpful /Friendly 


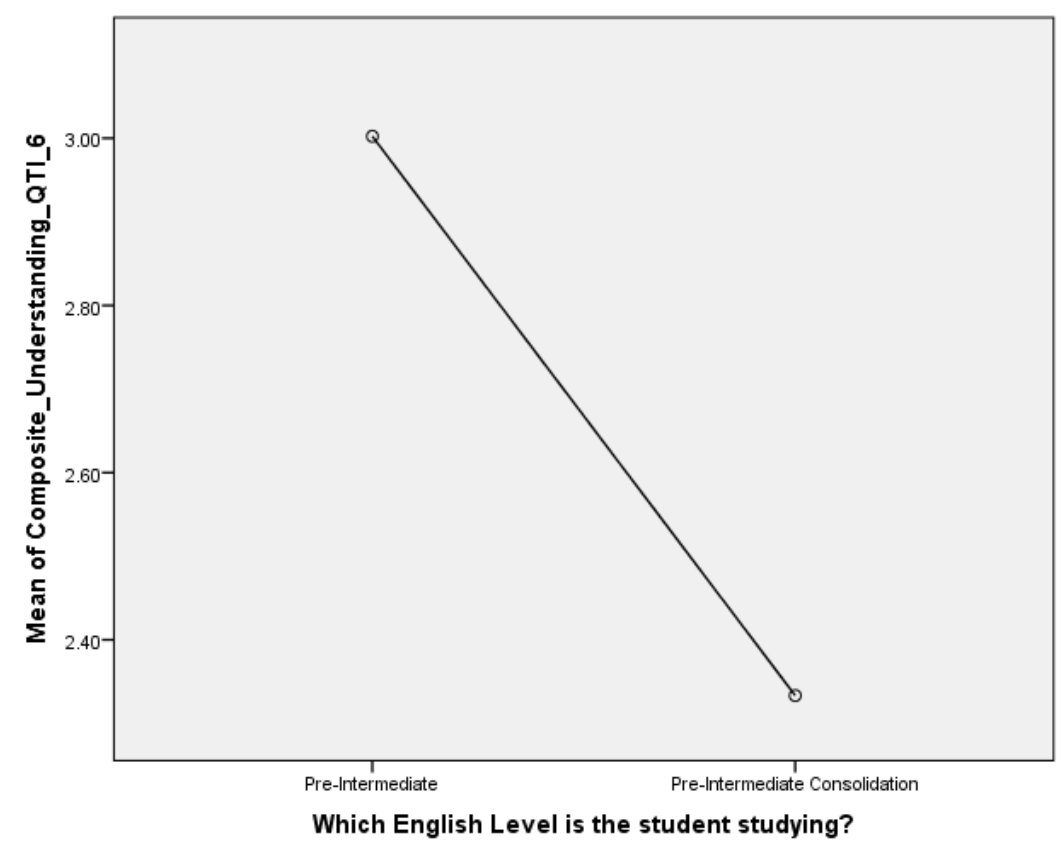

Figure 10. Difference between Pre-Intermediate Students in Understanding

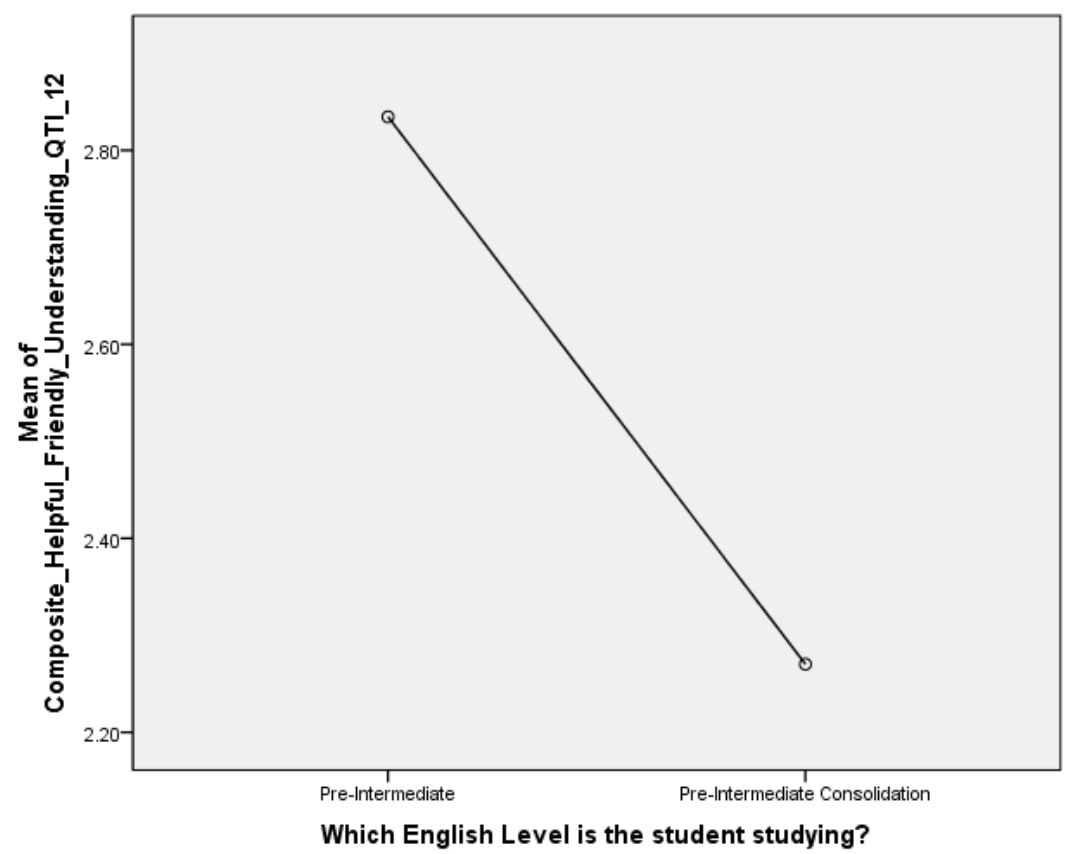

Figure 11. Difference between Pre-Intermediate Students in Total QTI

Analysis of variance showed a significant difference between Pre-Intermediate and PreIntermediate Consolidation students in their social engagement with the teacher, F $(1,66)=$ $5.37, \mathrm{p}=.024$, in their understanding $\mathrm{F}(1,66)=6.51, \mathrm{p}=.013$ and in the total helpful, friendly, understanding scale $\mathrm{F}(1,66)=4.49, \mathrm{p}=.038$. 


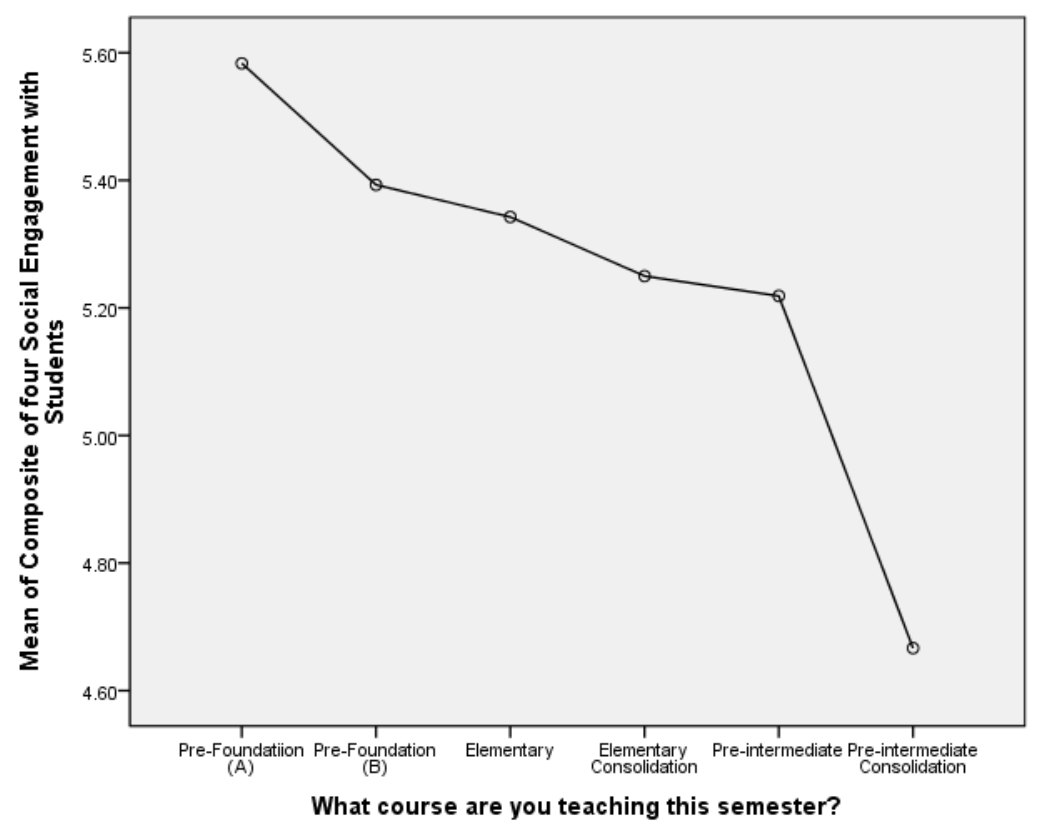

Figure 12. Difference between Teachers in Social Engagement with Students

Teachers' data also show that Pre-Foundation A teachers were more socially engaged with their students, which agrees with the students' data, but social engagement was not significantly correlated with teachers' data. Another limitation is that the number of teachers was too small in each level, 2 in Elementary Consolidation, 3 in Pre-Intermediate Consolidation, 8 in PreIntermediate, 27 in Elementary, 6 in Pre-Foundation A and 14 in Pre-Foundation B.

\section{Analysis and Discussion}

These results agree with Klassen, Yerdelen \& Durksen (2013) that social engagement with the students is considered the main factor in teaching. Social Engagement with the students is also not related to the students' level. As we can see, the students with the lowest level of English level were more socially engaged with their teachers than the students with the higher level of English. This also encourages the teachers to teach the students with the lowest English level and take advantage of this social engagement to increase students' level. Williams (1997) also pointed out that learning- teaching is a social process and that it depends on teachers' views about the students despite the methods or the curriculum used for teaching.

Furthermore, Petrides (2006) confirms that teachers' motivation is very important to create students' positive attitudes to learn the language and the teachers should also be qualified for teaching. This means that teachers' positive engagement towards teaching can transfer to the students and motivate them to learn the language. Teachers' engagement keeps changing according to the external factors that the teachers are exposed to. For example, teachers' engagement has decreased during the semester could be because of the students' low results as the teachers mentioned during the interview. This also agrees with Meijman, Mulder, Drenth 
\& Thierry (1998) that the environment is very important to increase the motivation and dedication to work.

Hakanen et al. (2006) also confirm that the high demands that the teachers experience may influence their social interaction with their students. In addition, having external job resources such as supportive organisational climate can enhance teachers' engagement more than personal resources such as self-efficacy and self-esteem.

The analysis also shows that emotional engagement is a very important aspect of teacher engagement. This result support Bakker, Albrecht\&Leiter (2011) that engagement is "emotional involvement or commitment". Collie, Shapka, \& Perry (2011) affirm that teacher commitment is related to students' emotional and social engagement. This appears in the analysis when the students with the lowest English level were the most socially engaged with their teachers. This could be related to their teachers having more commitment to teaching despite the students' low English level. Results also show that teachers with less teaching experience are more emotionally and socially engaged than other teachers. This is also supported by Klassen et al (2013) that teachers who have just start teaching may experience high levels of social engagement, but their cognitive engagement could be less than experience teachers.

\section{Limitations}

There are many limitations to this study. For example, the research was applied in one institution and did not include any other educational institutes. This could be because due to the sensitivity of the research it may be difficult to get approval from any other educational workplaces.

In addition, although students' learning beliefs come from school systems were they get to be used to for long years, schools teachers or any of the policy makers in schools were not included. This could be because that there was enough explanation in the recent literature review about the school system and the difficulties the system is facing until today. Moreover, some of the teachers who were interviewed in this study worked in school before or worked on a research related to schools including observations of some of the teachers and trainers working in schools.

Furthermore, all the teachers participated in this study were expatriate teachers since these were the only teachers teaching during that semester. Including Omani teachers may not make a big difference, since the big challenge comes from the students' educational and cultural background and not from the teachers. As some students state that having a teacher from a different culture may encourage them to have strong relationship and to practice the language.

Having only three diaries during a semester may also be considered a limitation. The researcher was planning to have more diaries, but because of the limit of time which was only a semester to apply this research. In addition, it will be difficult for the teachers to complete more than three diaries during the semester due to their teaching responsibilities. There also should be the 
same time limit between each diary.

\section{Conclusions}

In conclusions, Teacher Engagement is an important factor for achieving teacher's well-being and Teacher Engagement should be checked by the management from time to time, so that any job demands will be revised and solved. In addition, there should be good relationship between teachers and students. Finally, students should get enough support to change their learning beliefs which are affecting their teacher's engagement and may affect students' employment in the future.

\section{References}

Akkari, A. (2004). Education in the Middle East and North Africa: The Current Situation and Future Challenges. International Education Journal, 5(2), 144-153.

Al-Issa, A. S. (2006 b). The cultural and economic politics of English language teaching in Sultanate of Oman. Asian EFL fJournal, 8(1), 194-218.

Al-Issa, A. S. M. (2002). An ideological and discursive analysis of English language teaching in the Sultanate of Oman. Unpublished doctoral dissertation, University of Queensland, Australia.

Al-Issa, A. S., \& Al-Bulushi, A. H. (2012). English language teaching reform in Sultanate of Oman: The case of theory and practice disparity. Educational Research for Policy and Practice, 11(2), 141-176. https://doi.org/10.1007/s10671-011-9110-0

Al-Toubi, S. (1998). A perspective on change in the Omani ELT curriculum: structural to communicative. Unpublished masters dissertation. University of Bristol, England.

Al-Zufairy, A. W. M. (2003). Unemployment in the Gulf countries: Reasons and remedies. Applied Econometrics and International Development, 3(3).

Bakker, A. B., Albrecht, S. L., \& Leiter, M. P. (2011). Key questions regarding work engagement. European Journal of Work and Organizational Psychology, 20(1), 4-28. https://doi.org/10.1080/1359432X.2010.485352

Collie, R. J., Shapka, J. D., \& Perry, N. E. (2011). Predicting teacher commitment: The impact of school climate and social-emotional learning. Psychology in the Schools, 48(10), 10341048. https://doi.org/10.1002/pits.20611

Hakanen, J. J., Bakker, A. B., \& Schaufeli, W. B. (2006). Burnout and work engagement among teachers. Journal of school psychology, 43(6), 495-513. https://doi.org/10.1016/j.jsp.2005.11.001

Klassen, R. M., Yerdelen, S., \& Durksen, T. L. (2013). Measuring Teacher Engagement: Development of the Engaged Teachers Scale (ETS). Frontline Learning Research, 1(2), 
33-52. https://doi.org/10.14786/flr.v1i2.44

Matthew, M. P. (2001). Match or mismatch? Learning styles and teaching styles in EFL. International journal of applied linguistics, 11(1), 1-20. https://doi.org/10.1111/14734192.00001

Meijman, T. F., Mulder, G., Drenth, P., \& Thierry, H. (1998). Psychological aspects of workload. Handbook of Work and Organizational Psychology, 2.

Mondiale, B. (2008). The road not traveled: Education reform in the Middle East and North Africa. The World Bank : Washington, DC.

Petrides, J. R. (2006). Attitudes and motivation and their impact on the performance of young English as a foreign language learners. Journal of language and learning, 5(1), 1-20.

Williams, M. (1997). Psychology for language teachers : a social constructivist approach. Cambridge; New York: Cambridge University Press. https://doi.org/10.1177/0261927X970163001

\section{Copyright Disclaimer}

Copyright for this article is retained by the author(s), with first publication rights granted to the journal.

This is an open-access article distributed under the terms and conditions of the Creative Commons Attribution license (http://creativecommons.org/licenses/by/3.0/). 